\title{
Natural Regeneration of Beech Forests in the Strict Protected Area of the Plitvice Lakes National Park
}

\author{
Tomislav Dubravac ${ }^{1 凶}$, Stjepan Dekanić ${ }^{2}$, Vladimir Novotny ${ }^{3}$, \\ Josip Milašinčić ${ }^{1}$
}

\footnotetext{
${ }^{1}$ Croatian Forest Research Institute, Cvjetno naselje 41, 10450 Jastrebarsko, Croatia

2 Institute for Research and Development of Sustainable Ecosystems, Jagodno 100a, 10415 Novo Čiče, Velika Gorica, Croatia

${ }^{3}$ Croatian Forest Research Institute, Trnjanska cesta 35, 10000 Zagreb, Croatia

$\varangle$ Corresponding author: e-mail: tomod@sumins.hr
}

Citation:

DUBRAVAC T, DEKANIĆ S, NOVOTNY V, MILAŠINČIĆ J 2013 Natural Regeneration of Beech Forests in the Strict Protected Area of the Plitvice Lakes National Park. South-East Eur For 4 (2): 95-103

\begin{abstract}
Background and Purpose: The study presents the results of an investigation of regeneration processes, growth, development and survival of young growth by field measurement and three-dimensional visualization of horizontal and vertical structure. The results are based on the ten-year investigation (1998-2009) on a permanent experimental plot in a mountain beech forest with dead nettle tree (Lamio orvale - Fagetum sylvaticae Ht. 1938) in conditions of passive protection.
\end{abstract}

Materials and Methods: Basic structural indicators were measured (diameter at breast height and height), structural crown elements (size and shape, ground cover crowns) and the occurrence and survival of young growth as the basic conditions of natural regeneration. Particular emphasis in the investigation was paid to the development of crown structures and the process of natural regeneration during the 10 year period.

Results and Conclusions: Investigation indicates the occurrence of young growth regeneration cores arising as a result of the die-back of one dominant beech tree with horizontal crown projections of 145 $\mathrm{m}^{2}$ which initiated the possibility of natural regeneration. The greatest change occurred in the beech seedling count, whose numbers increased fourfold from 3556 plants per hectare in 1998 to 12694 plants per hectare in 2009 . The share of beech seedlings increased from $8.7 \%$ to $22.6 \%$ of all species of young growth and shrubs. Thus beech became dominant among the tree species regeneration. However, the majority of the young plants of beech are of poor quality and thus their further development in conditions of passive protection is questionable. The investigations also showed the possibility of a new approach to the study of the dynamics of crown structures and the process of natural regeneration by methods of three-dimensional visualization of horizontal and vertical structures. The methods presented offer a more graphic illustration of the development of stands and high quality presentation of the obtained results. For a long-term scientifically based plan, with the aim of reaching the most favourable decisions on the future of forest stands in protected areas, particularly in today's conditions of climatic changes, continuous improvement and expansion of monitoring methods by means of a network of permanent experimental plots in all protected forest areas is necessary.

Keywords: forest reserve, passive protection, close-to-nature-forestry, crown structure, natural regeneration, beech (Fagus sylvatica L.). 


\section{INTRODUCTION}

Almost half of the continental territory of the Republic of Croatia (48\%) is covered by forests. Of the total forest areas approximately $56 \%$ consists of beech dominated forests, beech forests with sporadic sessile flowered oak, and mixed beech-fir forests [1]. In contrast to many countries, where the natural composition of the forest has been significantly changed by the activity of man, in Croatia a large part of the forests have retained its natural characteristics mainly due to the endeavours of the foresters and the nature of forest management based on the principles of sustainable development. This determined the stability and conservation of forest ecosystems and offered the possibility of establishing national parks during the middle and second half of the past century, in which the main, or one of the main, basic natural phenomena are the forests. The Plitvice Lakes National Park, one of eight national parks in Croatia, was established in 1949 for the protection of the hydrologic system of the lakes, forests and other ecosystems, and natural phenomena. In recognition of the great importance of the forest for the future of the Plitvice Lakes National Park, employees of the Croatian Forest Institute (formerly Forest Institute, Jastrebarsko) established four forest reserves with a total surface area of 1347 ha: Medveđak (1976), Čorkova uvalaČudinka (1977), Kik-Visibaba (1979) and Rječica-Javornik (1981). The basic objective of establishing forest reserves was to determine the basic (zero) condition of vegetation, determine structural relations and to monitor the further growth and development of forest ecosystems, particularly the condition and possibility of their natural regeneration as the basic factor for permanent forest ecosystem sustainability and survival.

This problem has been studied by many forest experts in Croatia. Seventy years ago prof. I. Horvat began the first systematic phytocoenological investigation in the Risnjak National Park. The start of forestry scientific research in virgin forests of Croatia can be attributed to the investigations of Corkova uvala in the Plitvice Lakes National Park, which were commenced by academician Milan Anić in 1957. With the object of monitoring the development of forests in natural conditions in the area of the Plitvice Lakes National Park the investigation of Cestar et al. [2] should be mentioned, who, after carrying out typological investigations, showed that the method of performed management did not encourage the occurrence of young growth, particularly of beech. Hren [3] investigated the structure of the beech virgin forest "Ramino korito", and Prpić [4] investigated the characteristics of the beech-fir virgin forest "Čorkova uvala" in the Plitvice Lakes National Park. Klepac [5, 6] advocated active protection of the forests in the Plitvice Lakes National Park, and in 1994 proposed ecological management of the forests with emphasis on the need to enable permanent natural regeneration of forests. In his investigation Novotny et al. [7] pointed to the growth and development of basic structural elements and elements of regeneration in the Plitvice Lakes National Park.

These investigations, with periodic measurements on permanent experimental plots, carried out by employees of the Croatian Forest Research Institute (basic structural elements, indicators of growth structures and development of tree crowns, including the number and quality of young growth), indicate that the possibility of satisfactory natural regeneration in national parks is questionable [8-14]. The aforementioned investigations showed that, although nature is continuously active, we cannot be satisfied only with its activity. Long-term study has shown that passive protection clearly does not give the expected results.

This study aimed to investigate regeneration processes, growth, development and survival of young growth in a mountain beech forest with dead nettle tree (Lamio orvale Fagetum sylvaticae $\mathrm{Ht}$. 1938) in conditions of passive protection. For that purpose field 
measurements on a permanent experimental plot in 1998 and 2009 were conducted as well three-dimensional visualization of horizontal and vertical structure.

\section{MATERIALS AND METHODS}

\section{Study Area}

The investigation was performed in the "Medveđak" Forest Reserve on a permanent experimental plot in a natural stand of mountain beech forest with dead nettle (Lamio orvale-Fagetum sylvaticae Ht.1938) $570 \mathrm{~m}$ above sea level (Figure 1). The reserve is situated within a larger forest complex of beech forests, in the north-eastern part of the "Plitvice Lakes" National Park. The reserve comprises three compartments with a total area of 156.3 ha. The highest point of the reserve is $875 \mathrm{~m}$, and the lowest $580 \mathrm{~m}$ above sea level. The reserve is located on a geological base of limestone with three soil types. On the high positions and on the ridges is humus (black soil) on limestone (10\%), on the steep slopes shallow brown soil on limestone $(20 \%)$, on the less steep slopes moderately deep brown soil on limestone (40\%), and in karst sinkholes is loessial soil or illimerised soil (30\%) [9]. Inclination ranges from $10^{\circ}$ to $25^{\circ}$. In the south-eastern lowest part of the reserve are karst sinkholes, from which the terrain rises up towards the north-east up to the highest point, and again over the ridge descends towards the north and north-east.

\section{Data Collection}

In 1998 a permanent experimental plot was established, 1 ha in size (plot coordinates: $\mathrm{N}=44^{\circ} 53^{\prime} 09^{\prime \prime} ; \mathrm{E}=15^{\circ} 38^{\prime} 01^{\prime \prime}$ ) according to the method of Dubravac and Novotny [15] as a part of a network of permanent experimental plots established in the national parks of Croatia (Risnjak, Plitvice Lakes, Paklenica, Mljet, Brijuni). The plots were established with the aim of monitoring the dynamics of forest ecosystems in conditions of strict protection of nature. The age of the stand at the time
FIGURE 1. Beech stand in the Medveđak Forest Reserve

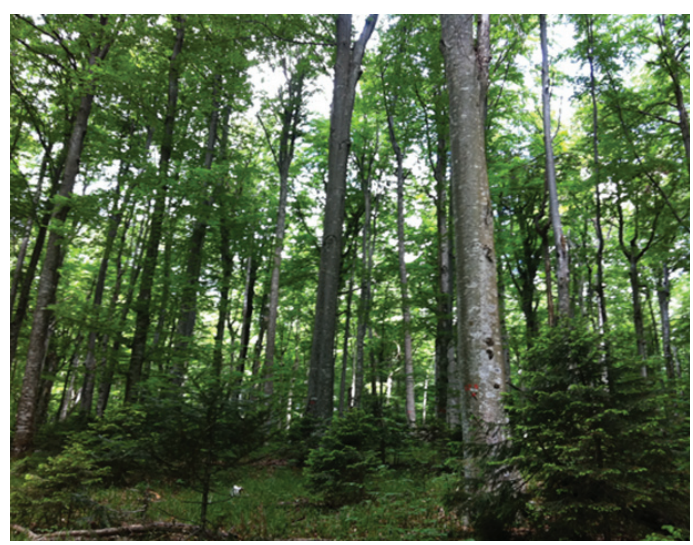

of the establishment of the plot was 147 years. All trees with diameter at breast height (DBH) greater than $7.5 \mathrm{~cm}$ were marked and their basic characteristics measured (DBH, tree height and stem length). In the most homogenous part of the plot a sub-plot was set up, $60 \mathrm{~m} \times 60 \mathrm{~m}$ in size, on which the spatial arrangement of the trees was recorded, their horizontal crown projections were mapped. Furthermore, elevation data of each tree were recorded, according to which a digital terrain model (DTM) was created (Figure 2). In three

strips for regeneration monitoring

tree positions

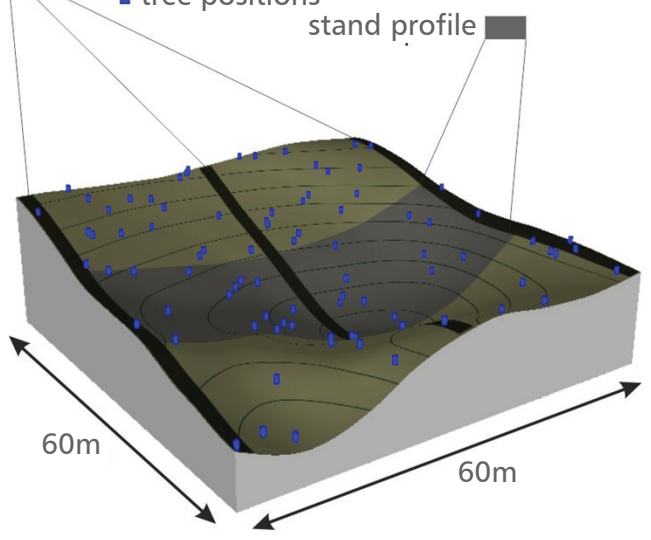

FIGURE 2. Digital terrain model (DTM) of the experimental plot with basic measuring elements 
strips, $2 \mathrm{~m} \times 60 \mathrm{~m}$ (total surface area 360 $\mathrm{m}^{2}$ ), the height structure of young growth and shrub layer was recorded and they were grouped into the height classes $(<30 \mathrm{~cm} ; 31$ $60 \mathrm{~cm} ; 61-130 \mathrm{~cm} ; 131-150 \mathrm{~cm} ; 151-200 \mathrm{~cm}$; 201-250 cm). Ten years later (2009) DBH and height of all trees were measured again, and on the strips the structure of young growth and shrub layer was recorded according to height classes and species. The horizontal projections of crowns were measured on the trees on the part of the plot (20 m x $60 \mathrm{~m})$, for comparison with the changes in the vertical profile of the stand between the two measurements. More information on data collection procedure could be found in earlier authors' works [9, $10,12,16]$. On the two occasions (1998 and 2009) dimensions of young growth which developed after the die-back of one of the dominant beech were also recorded and it was grouped into already mentioned height classes. ArcMap programme was used for digitalization of horizontal crown projections and production of the DTM. For preparation and analysis of data MS Excel was used and for visualization of stands and vertical profile Stand Visualization System and EnVision (USDA Forest Service, USA) programmes were used.

\section{RESULTS}

Basic structural characteristics of the experimental plot are shown in Table 1 . Comparing the obtained data with growth and yield tables [17] which have volume on I. cite class of $646 \mathrm{~m}^{3} \cdot \mathrm{ha}^{-1}$, it may be seen that the obtained volume of the researched stand is considerably higher, mainly due to passive protection of the stand and absence of the management activities. More details on the stand structure elements and comparison between two measurements (1998 and 2009) may be found in the paper of Novotny et al. [7].

\section{Crown structure}

From the layout of horizontal projections of crowns in the first measurement in 1998, it was determined that the crown cover of ground amounted to $96 \%$. Mean area of a horizontal crown projection amounted to $53.67 \mathrm{~m}^{2}$ ranging from 5.94 to $158.36 \mathrm{~m}^{2}$. Crown projection area of trees exhibits a nonlinear relationship with the $\mathrm{DBH}$, in the form of the power function (Figure 4).

In the left lower quadrant of the experimental plot an advanced regeneration was found in the opening of the stand canopy, which had resulted from the die-back of one dominant beech tree from the upper canopy layer prior to the establishment of the plot. From the DBH of the dead tree, the area of the horizontal crown projection was estimated to be $145 \mathrm{~m}^{2}$. The opening created in the canopy layer stimulated the occurrence of the advanced regeneration. In order to estimate the growth dynamics of the crown structure development between the two measurements, two stand profiles were set up on a part of the plot, $20 \mathrm{~m} \times 60 \mathrm{~m}$ in size (Figure 5). In the first measurement the total area of the horizontal crown projections of 27 trees in the profile amounted to $1,492.24 \mathrm{~m}^{2}$, with the average size of projection area for one tree at 55.27 $\mathrm{m}^{2}$. Prior to the second measurement dieback occurred in 3 trees of the total area of the horizontal crown projection of $69.27 \mathrm{~m}^{2}$. However, an increase occurred in the mean

TABLE 1. Basic stand structure elements (stem number $-N$, basal area $-B A$, volume $-V$ ) and average values (diameter at breast height $-\mathrm{DBH}$, height $-h$, basal area $-b a$, volume $-v$ ) of the beech trees of the experimental plots in 2009

\begin{tabular}{cccccccc}
\hline $\begin{array}{c}\text { Measurement } \\
\text { year }\end{array}$ & $\begin{array}{c}\mathbf{N} \\
\text { trees } \cdot \mathrm{ha}^{-1}\end{array}$ & $\begin{array}{c}\mathrm{BA} \\
\mathrm{m}^{2} \cdot \mathrm{ha}^{-1}\end{array}$ & $\begin{array}{c}\mathbf{V} \\
\mathrm{m}^{3} \cdot \mathrm{ha}^{-1}\end{array}$ & $\begin{array}{c}\mathrm{DBH} \\
\mathrm{cm}\end{array}$ & $\begin{array}{c}\mathbf{h} \\
\mathrm{m}\end{array}$ & $\begin{array}{c}\text { ba } \\
\mathrm{m}^{2}\end{array}$ & $\begin{array}{c}\mathbf{v} \\
\mathrm{m}^{3}\end{array}$ \\
\hline 2009 & 291 & 45.68 & 803.07 & 41.1 & 27.1 & 0.15 & 2.46 \\
\hline
\end{tabular}



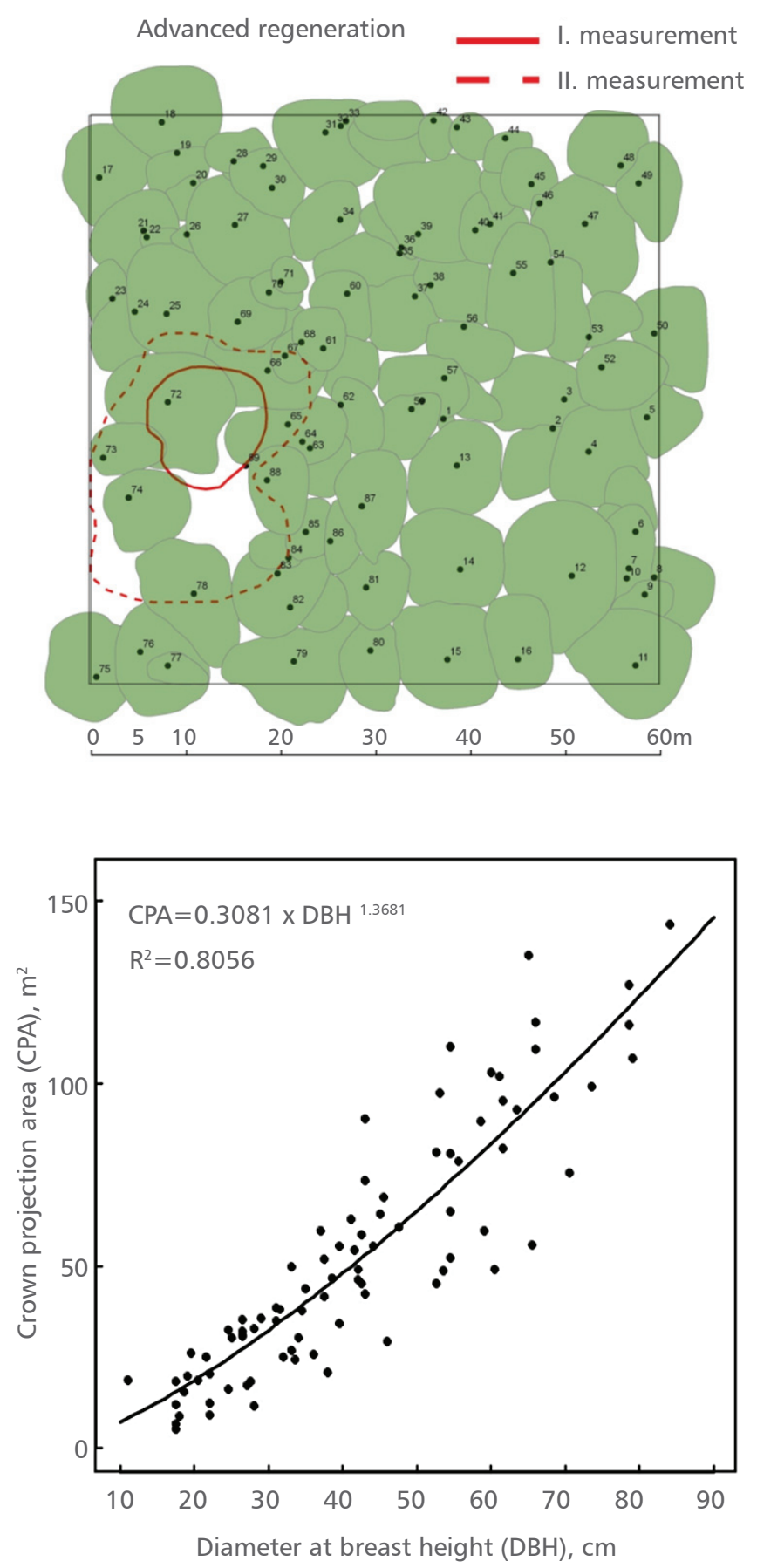

FIGURE 3. Horizontal projections of crowns (first measurement 1998) with advanced regeneration (1998 full line, 2009 broken line)
FIGURE 4. Relationship of the crown projection area (CPA) and the DBH area of crown projection per tree of 63.04 $\mathrm{m}^{2}\left(+7.77 \mathrm{~m}^{2}\right)$, and increase also occurred in the total area of the of horizontal crown projections of $1,512.89 \mathrm{~m}^{2}\left(+20.65 \mathrm{~m}^{2}\right)$. In the period between the two measurements no more significant changes occurred in the vertical canopy, regardless of the 3 missing trees. 
I. measurement
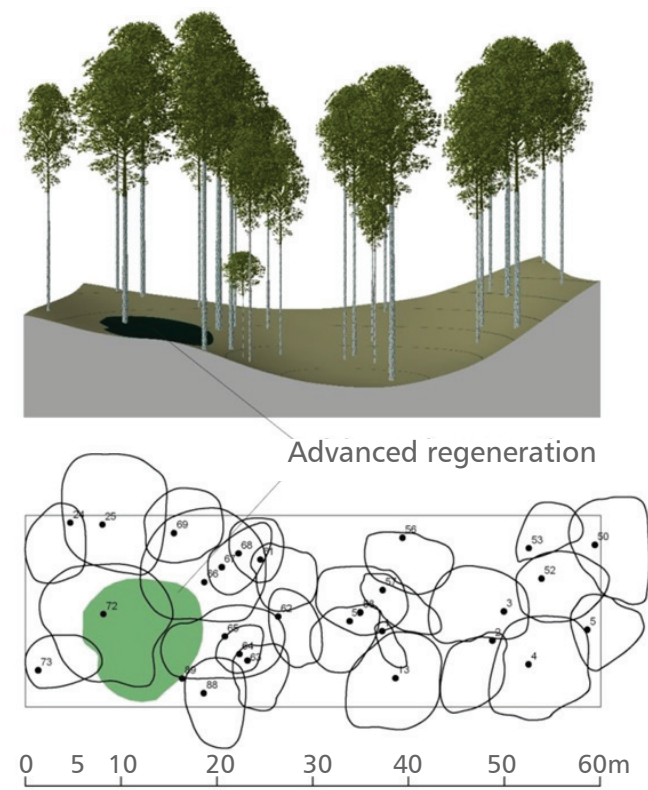

II. measurement
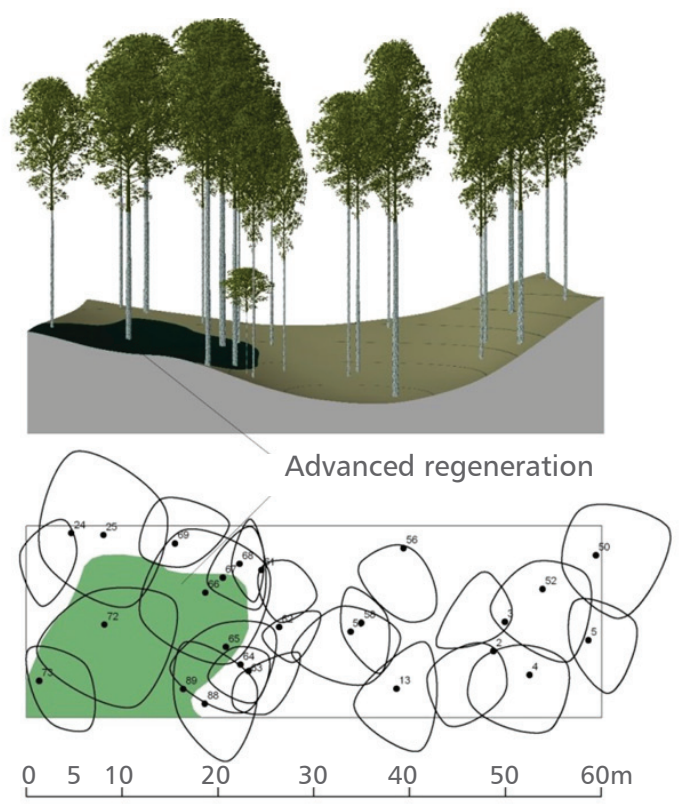

FIGURE 5. Scheme of the development of initiated advanced regeneration between two measurements

\section{Process of natural regeneration}

As has already been stated that the process of natural regeneration was mainly influenced by the opening of the canopy due to the die-back of one dominant beech tree and by development of advanced regeneration (Figure 5). The area of the advanced regeneration in 1998 amounted to 124.7 $\mathrm{m}^{2}$ which increased fourfold in the second measurement, to $512.2 \mathrm{~m}^{2}$. By measuring the numbers of the regeneration and shrubs on three strips (Figure 2) on total area of $360 \mathrm{~m}^{2}$ in 1998 and 2009, an increase in the overall number of plants from 40.8 to 56.2 plants per hectare, was determined (Table 2). The greatest changes occurred in the share of beech seedlings, the number of which increased fourfold from 3,556 plants per hectare in 1998 to 12,694 plants per hectare in the second measuring. In the percentage share common beech increased from $8.7 \%$ to $22.6 \%$ of all plants of young growth and shrubs, and took a dominant role among the young crop of trees. With regard to the height structure of the young beech trees, their increased number is most visible in height class up to $30 \mathrm{~cm}$ (Figure 6). The majority of the young beech plants is of poor quality and it is questionable how they will continue their further development in the conditions of passive protection.

Today, information on stand structure (spatial arrangement of trees, tree measurements, and particularly crown measurements) may be visually presented by means of one of numerous computer programmes. On the basis of a digital model of tree-crown projections, measured values in the field (tree heights, stem length, length and width of crowns) and standard bases, a threedimensional photo-realistic digital model of a stand was produced. In the production of the model the spatial arrangement of trees and phenotype of crown forms were taken into account [18]. In this investigation stand structure is visualized in the programme packet EnVision (USDA Forest Service, USA) which is shown in Figure 7. 
TABLE 2. Number of seedlings, saplings and shrubs per hectare in two measurements

* Acer pseudoplatanus L., , Picea abies (L,) H.Karst, Fraxinus excelsior L.

** Sambucus nigra L, Daphne mezereum L., Corylus avellana L. and others

\begin{tabular}{crrrrrrrrr}
\hline $\begin{array}{c}\text { Height } \\
\text { class } \\
(\mathrm{cm})\end{array}$ & \multicolumn{2}{c}{ Beech } & \multicolumn{2}{c}{$\begin{array}{c}\text { Other tree } \\
\text { species* }\end{array}$} & \multicolumn{2}{c}{ Shrubs** } & \multicolumn{2}{c}{ Total } \\
\hline to 30 & 1998 & 2009 & 1998 & 2009 & 1998 & 2009 & 1998 & 2009 \\
$31-60$ & 1417 & 1111 & 1056 & 1306 & 5500 & 3917 & 7972 & 6333 \\
$61-130$ & 556 & 1139 & 361 & 611 & 361 & 222 & 1278 & 1972 \\
$131-150$ & 28 & 139 & 56 & 28 & & & & 83 & 167 \\
$151-200$ & 28 & 83 & 167 & 111 & & 56 & 194 & 250 \\
$201-250$ & & 28 & 28 & 83 & & & 28 & 111 \\
\hline Total & 3556 & 12694 & 3222 & 3167 & 34028 & 40389 & 40806 & 56250 \\
\hline
\end{tabular}

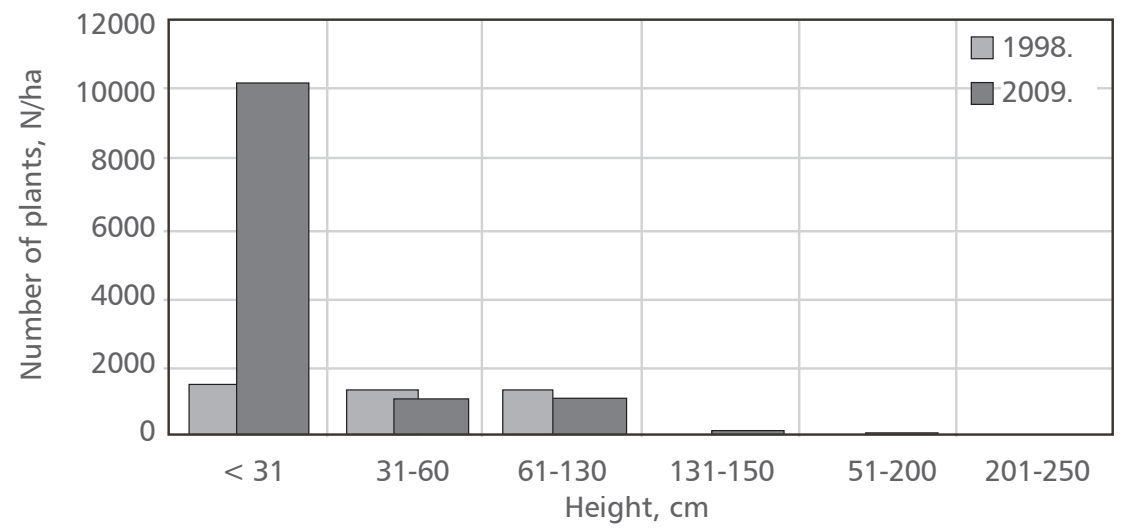

FIGURE 6. Height structure of young beech growth
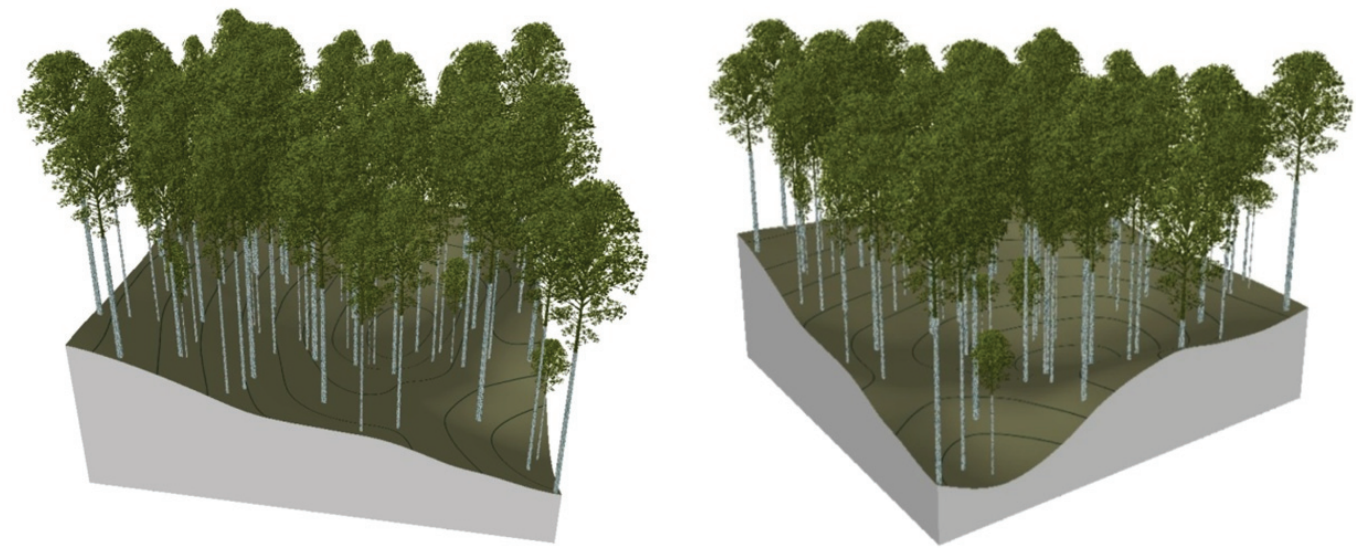

FIGURE 7. Visualization of beech stand on the experimental plot (En Vision), two views 


\section{DISCUSSION}

Although the observation was carried out in a relatively short period of time (10 years), the methods and results of this investigation present new contributions to understanding crown structure dynamics and the process of natural regeneration of pure beech stands in conditions of passive protection. Investigations so far [e.g. 19-24], also confirmed in this study, indicate that natural regeneration should be carried out on initiated regenerative cores, by opening the canopy in small areas and groups. Similar to this research, results of the research conducted by Rugani et al. [25] showed that gaps smaller than $500 \mathrm{~m}^{2}$ are the dominant driving force of stand development. Therefore, we think that opening canopy in small areas present the best form of regeneration for nature, especially in protected forest ecosystem. In order to attain scientifically based plans for deciding on the future of forest stands of protected areas, particularly in conditions of climatic changes today, it is necessary to constantly improve and broaden methods of monitoring by means of a network of permanent experimental plots in all protected forest areas. The possibilities offered by modern computerised models for high quality presentation of obtained knowledge should not be ignored. Furthermore, modern remote sensing methods and data (e.g. airborne images, satellite images, LiDAR) may be used for characterising forest dynamics on large-scale areas. For instances, Hobi [26] founded that high resolution satellite images (WorlView-2) have a large potential for forest canopy modelling (for characterising forests' gap dynamics).

By acknowledging existing laws and provisions in areas which are not under a regime of strict protection, it is necessary to assist natural processes which are already in progress in the forest ecosystems. The aforementioned activities are the fundamental method for optimization of priority functions of the forests with specific assignment. Such work should include two important principles: 1) high-production forest is biologically the most stable forest, which offers the greatest generally useful functions and 2) professional silvicultural activities are at the same time the condition and only way in which we can, on the one hand utilize productive functions of the forest, and on the other hand ensure the protection and natural regeneration in these forests.

Knowledge of these problems clearly indicate that increased engagement of the forestry profession is necessary, particularly in those protected areas whose basic phenomena, and most recognized characteristics, are forest ecosystems. In such cases forest interventions should be adapted to the preservation and natural characteristics of the forest ecosystems on particular sites. This is also confirmed by other researches conducted in the 'Medveđak' forest reserve $[20,24,27]$. Therefore, so called 'closeto-nature-forestry' silvicultural approach [19, 23, 28], with existed but reduced human activities, which is accepted in most of the Central European countries may be adapted in forest managing of Croatian Natural Parks, as well.

\section{REFERENCES}

1. CROATIAN FOREST LTD 2006 General Forest Management Plan of the Republic of Croatia (20062015). Approved by the Ministry of Agriculture, Forestry and Water Management, $566 p$

2. CESTAR D, HREN V, KOVAČEVIĆ Z, MARTINOVIĆ J, PELCER Z, BEZAK K, KRZNAR A, LINDIĆ V, VRBEK B, KREJČI V 1982 Natural forest reserve Medveđak (in Croatian). Rad - Šumar inst Jastrebar 50: 1-76

3. HREN V 1972 Ramino korito - beech virgin forest (in Croatian). Sumar list 96 (9-10): 315-324
4. PRPIĆ B 1972 Some characteristics of Čorkova uvala virgin forest (in Croatian). Sumar list 96 (910): $325-333$.

5. KLEPAC D 1984 Principi uređivanja šuma Nacionalnog Parka "Plitvička jezera" (in Croatian). Sumar list 108 (7-8): 319-335

6. KLEPAC D 1994 Ekološko uređivanja šuma u Nacionalnom Parku "Plitvička jezera" (in Croatian).

7. NOVOTNY V, BALENOVIĆ I, DUBRAVAC T, VULETIĆ D, DEKANIĆ S 2010: First results of monitoring of stand 
structure changes in unmanaged beech stands in NP Plitvice Lakes. South-East Eur For 1 (2): 91-98

8. KREJČI V, DUBRAVAC T 2001 Possibilites of Natinal Park Reforestation (in Croatian with English summary). Rad - Šumar inst Jastrebar 36 (2): 113122

9. DUBRAVAC T, KREJČI V, VRBEK B 2004 State of the Structure and Possibility of Natural Reforestation of Pure Beech Stands in the "Medvjeđak" Forest Reservation (in Croatian). Plitvički bilten 6: 179-200

10. DUBRAVAC T, VULETIĆ D, VRBEK B 2005 Natural reforestation and future of beech and fir forests in the Risnjak NP. Period biol 107(1): 73-79

11. DUBRAVAC T, BENKO M, ČAVLOVIĆ J 2005 The structure of uneven-aged stands in non-economic forests of national park Risnjak in Croatia. Ekol Bratislava 24 (4): 385-396

12. DUBRAVAC T, ČAVLOVIĆ J, ROTH V, VRBEK B, NOVOTNY V, DEKANIĆ S 2007 The structure and possibility of natural regeneration in managed and non-managed beech and fir forests in Croatia. Period biol 109 (1): 21-27

13. DUBRAVAC T, KREJČI V, DEKANIĆ S 2008 Effects of stand structure on regeneration dynamics of fir and beech forests in Risnjak national park. Glasnik za šumske pokuse 42: 57-74

14. DUBRAVAC T, DEKANIĆ S 2012 Silvicultural research in national parks in Croatia-example of National park "Risnjak" (oral presentation). In: Forestry Science and Practice for the Purpose of Sustainable Development of Forestry - 20 Years of the Faculty of Forestry in Banja Luka. 1-4 November 2012, Banja Luka, Bosnia and Herzegovina.

15. DUBRAVAC T, NOVOTNY V 1992 Methodology of thematic area-silviculture-gowth and increment applied in multidisciplinary project ecological economical forest valency types (in Croatian with English summary). Rad - Šumar inst Jastrebar 27 (2): 157-166

16. DUBRAVAC T, BOBINAC M, BARČIĆ D, NOVOTNY V, ANDRAŠEV S 2013 Growth dynamics of crown shapes in stands of pedunculate oak and common hornbeam. Period biol 115 (3): 331-338

17. ŠPIRANEC M 1975 Growth-yield tables for oaks, beech, hornbeam and sweet chestnut (in Croatian). Ibid. 25, pp 1-193

18. DUBRAVAC T 2005 Application of Digitalisation of Crowns and Method of Visualisation in a Study of Stand Structures (in Croatian with English summary). Rad - Šumar inst Jastrebar 40 (1): 53-72
19. VON OHEIMB G, WESTPHAL C, TEMPEL $H_{\text {, }}$ HÄRDTLE W 2005 Structural pattern of a nearnatural beech forest (Fagus sylvatica) (Serrahn, North-east Germany). Forest Ecol Manag 212 (1-3): 253-263. DOI: http://dx.doi.org/10.1016/j. foreco.2005.03.033

20. ANIĆ I 2007 The influence of stand structure and regeneration on the sustainability of fir-beech and beech forests in the National park Plitvice Lakes. 62 p. URL: http://bib.irb.hr/datoteka/326894. Microsoft_Word__ plitvice_2006_konacno_izvj.pdf

21. ANIĆ I, MIKAC S 2008 Structure, Texture And Regeneration Of Dinaric Beech-Fir Virgin Forest Of Corkova Uvala (in Croatian with English summary). Sumar list 132 (11-12): 505-515

22. ŁYSIK M 2008 Ten Years of Change in GroundLayer Vegetation of European Beech Forest in the Protected Area (Ojców National Park, South Poland). Pol J Ecol 56 (1): 17-31

23. MADSEN P, HAHN K 2008 Natural regeneration in a beech-dominated forest managed by close-tonature principles - a gap cutting based experiment. Can J For Res 38 (7): 1716-1729. DOI: http://dx.doi. org/10.1139/X08-026.

24. MAGDIĆ N 2010 Small-scale natural regeneration of the beech forests in the Plitvice lakes National park (in Croatian with English summary). MSc thesis, Faculty of Forestry, University of Zagreb, Zagreb, $62 \mathrm{p}$

25. RUGANI T, DIACI J, HLADNIK D 2013 Gap Dynamics and Structure of Two Old-Growth Beech Forest Remnants in Slovenia. PLoS One 8 (1): e52641. DOI: http://dx.doi.org/10.1371/journal.pone.0052641

26. HOBI M L 2013 Structure and disturbance patterns of the largest European primeval beech forest revealed by terrestrial and remote sensing data. PhD thesis, ETH Zurich, Zurich, Switzerland, $166 \mathrm{p}$

27. ANIĆ । 2011 Dynamics of beech-fir forests under permanent protection. In: Dujmović A (ed) Proceedings of the Scientific-professional conferrence of the Plitvice Lakes National Park, Plitvice Lakes, Croatia, 15-16 October 2009. Public Institution "Plitvice Lakes National Park", Plitvice Lakes, Croatia, pp 104-119

28. PARVIAINEN J 2005 Virgin and natural forests in the temperate zone of Europe. For Snow Landsc Res 79 (1-2): 9-18 


\section{REFERENCES}

1. WENG Q 2009 Remote Sensing And GIS Integration - Theories, Methods and Application. The McGraw-Hill Education, Inc., p 416

2. GAJSKI D 2007 Basics of airborne laser scanning. Ekscentar 10: 16-22 (in Croatian)

3. REUTEBUCH S E, ANDERSON H-E, MCGAUGHEY B J 2005 Light Detection and Ranging (LIDAR): An Emerging Tool for Multiple Resource Inventory. $J$ Forest 103 (6): 286-292

4. CORONA P, CARTISANO R, SALVATI R, CHIRICI G, FLORIS A, DI MARTINO P, MARCHETTI M, SCRINZI G, CLEMENTEL F, TRAVAGLINI D, TORRESAN C 2012 Airborne Laser Scanning to support forest resource management under alpine, temperate and Mediterranean environments in Italy. European Journal of Remote Sensing 45: 27-37

5. CARTER J, SCHMID K, WATERS K, BETZHOLD L, HADLEY B, MATAOSKY R, HALLERAN J 2012 Lidar 101: An Introduction to Lidar Technology, Data, and Applications. NOAA Coastal Services Center Charleston, SC. Available at: http://csc.noaa.gov/ digitalcoast/_/pdf/lidar101.pdf (Accessed: 20 February 2013)

6. VOSSELMAN G, MASS H G 2010 Airborne and Terrestrial Laser Scanning. Whittles Publising, Dunbeath, $\mathrm{p} 336$

7. PETRIE G, TOTH C K 2008 Introduction to Laser Ranging, Profiling and Scanning. In: Shan J, Toth C K (eds) Topographic Laser Ranging and Scanning: Principles and Processing. CRC Press/Taylor \& Francis, London, pp 1-28

8. WEHR A, LOHR U 1999 Airborne laser scanning - an introduction and overview. ISPRS J Photogramm 54 (2): 68-82

9. LIM K, TREITZ P, WULDER M, ST-ONGE B, FLOOD M 2003 LIDAR remote sensing of forest structure. Prog Phys Geog 27 (1): 88-106
10. HYYPPÄ J, HYYPPÄ H, LITKEY P, YU, HAGGRÉN H, RÖNNHOLM P, PYYSALO U, PITKÄNEN J, MALTAMO M 2004 Algorithms and methods of airborne laser-scanning for forest measurements. International Archives of Photogrammetry, Remote Sensing and Spatial Information Sciences 36 (8): 1682-1750

11. MONNET J-M 2012 Airborne Laser Scanning for Forest Applications - State-of-the-Art. p 23. Available at: http://www.alpine-space.eu/uploads/tx_txrunningprojects/Airborne Laser Scanning for Forest Applications_-_State_of_the_Ärt.pdf (Accessed: 20 February 2013)

12. KOBLER A, PFEIFER N, OGRINC P, TODOROVSKI U, OŠTIR K, DŽEROSKI S 2007 Repetitive interpolation: A robust algorithm for DTM generation from Aerial Laser Scanner Data in forested terrain. Remote Sens Environ 108 (1): 9-23

13. KOBAL M 2011 The influence of stand, soil and microsite conditions on growth and development of silver fir (Abies alba Mill.) in high karst of Snežnik. Dissertation, University of Ljubljanja, Ljubljana, p 148

14. KOBLER A 2011 New methods of processing aerial laser scanner data for forest ecosystem monitoring. Dissertation, University of Ljubljanja, Ljubljana, p 131

15. HEINIMANN H R, BRESCHAN J 2012 Pre-Harvest Assessment based on LiDAR data. Croat J For Eng 33 (2): 169-180

16. BALTSAVIAS E P 1999 Airborne laser scanning: basic relations and formulas. ISPRS J Photogramm 54 (2-3): 199-214

17. YU $X$, HYYPPÄ J, HOLOPAINEN M, VASTARANTA M 2010 Comparison of Area-Based and Individual TreeBased Methods for Predicting Plot-Level Forest Attributes. Remote Sens 2 (6): 1481-1495

18. BALTSAVIAS E P 1999 A comparison between photogrammetry and laser scanning. ISPRS J Photogramm 54 (2-3): 83-94 
19. TURNER R 2007 An overview of Airborne LIDAR applications in New South Wales state forests. In: Growing Forest Values. Proceedings of ANZIF 2007 conference, Coffs Harbour. Institute of Foresters of Australia, Canberra, p 22. Available at: http://www. forestry.org.au/pdf/pdf-public/conference2007/papers/Turner\%20Russell\%20Lidar.pdf (Accessed: 20 November 2012)

20. VENEZIANO D, SOULEYRETTE R, HALLMARK S 2002 Evaluation of LiDAR For Highway Planning, Location and Design. In: Conference Proceedings of Integrated Remote Sensing at the Global, Regional and Local Scale. ISPRS Comission I. Mid-Term Symposium in conjunction with Pecora 15/Land Satellite Information IV Conference, Denver, USA, p 10. Available at: http://www.isprs.org/proceedings/ XXXIV/part1/paper/00029.pdf (Accessed 25 November 2012).

21. PETRIE G, TOTH CK 2008 Airborne and Spaceborne Laser Profilers and Scanners. In: Shan J, Toth C K (eds) Topographic Laser Ranging and Scanning: Principles and Processing. CRC Press/Taylor \& Francis, London, pp 29-87

22. WULDER M A, WHITE J C, NELSON R F, NAESSET $E$, ØRKA $H$, COOPS N C, HILKER T, BATER C W, GOBAKKEN T 2012 Lidar sampling for large-area forest characterization: A review. Remote Sens Environ 121: 196-209

23. RAHMAN M Z A, GORTE B G H, BUCKSCH A K 2009 $A$ new method for individual tree delineation from airborne LiDAR. In: Proceedings Silvilaser 2009, Austin, Texas, USA, pp 1-10

24. BALTSAVIAS E P 1999 Airborne laser scanning: existing systems and firms and other resources. ISPRS J Photogramm 54 (2-3): 164-198

25. LEFSKY M, COHEN W, PARKER G, HARDING D 2002 Lidar remote sensing for ecosystem studies. Bioscience 52 (1): 19-30

26. HYYPPÄ J, HYYPPÄ $H, Y U X, K$ KAARTINEN $H$, KUKKO A, HOLOPAINEN M 2008 Forest Inventory Using Small-Footprint Airborne Lidar. In: Shan J, Toth C $\mathrm{K}$ (eds) Topographic Laser Ranging and Scanning: Principles and Processing. CRC Press/Taylor \& Francis, London, pp 335-370

27. VAN LEEUWEN M, NIEUWENHUIS M 2010 Retrieval of forest structural parameters using LiDAR remote sensing. Eur J Forest Res 129 (4): 749-770

28. GATZIOLIS D, ANDERSEN H-E 2008 A guide to LIDAR data acquisition and processing for the forests of the Pacific Northwest. Gen. Tech. Rep. PNWGTR-768. Portland, OR: U.S. Department of Agri- culture, Forest Service, Pacific Northwest Research Station, p 32. Available at: http://www.fs.fed.us/ pnw/pubs/pnw_gtr768.pdf (Accessed: 15 October 2012)

29. EVANS J S, HUDAK A T, FAUX R, SMITH A M S 2009 Discrete Return Lidar in Natural Resources: Recommendations for Project Planning, Data Processing, and Deliverables. Remote Sens 1 (4): 776-794

30. DIAZ J C F 2011 Lifting the canopy veil: airborne LiDAR for archeology of forested areas. Imaging Notes Magazine 26 (2): 31-34. Available at: http:// www.imagingnotes.com/go/article freeJ.php?mp id =264\#1 (Accessed: 16 October 2012)

31. HYYPPÄ J, YU X, HYYPPÄ H, MALTAMO M 2006 Methods of airborne laser scanning for forest information extraction. In: International Workshop 3D Remote Sensing in Forestry Proceedings (EARSeL SIG Forestry), Vienna, pp 63-78

32. CHASMER L, HOPKINSON C, TREITZ P 2006 Investigating laser pulse penetration through a conifer canopy by integrating airborne and terrestrial lidar. Can J Remote Sens 32 (2): 116-125

33. DUBAYAH R O, DRAKE J B 2000 Lidar remote sensing for forestry. J Forest 98 (6): 44-46

34. WATERSHED SCIENCES INC 2010 Minimum LiDAR Considerations in the Pacific Northwest. Available at: http://www.oregongeology.org/sub/projects/ olc/minimum-lidar-data-density.pdf (Accessed: 10 March 2013)

35. RÖNNHOLM P, HONKAVAARA E, LITKEY P, HYYPPÄ $\mathrm{H}$, HYYPPÄ J 2007 Integration of laser scanning and photogrammetry. In: Proceedings of: IAPRS 2007 Vol. XXXVI, Part 3/W52, Espoo, Finland, pp 355-362

36. NEX F 2010 Multi-Image Matching and LiDAR data new integration approach. Dissertation, Politicnico di Torino, Torino, p 235

37. WULDER M A, BATER C W, COOPS N C, HILKER T, WHITE J C 2008 The role of LiDAR in sustainable forest management. For Chron 84 (6): 807-826

38. ROSETTE J, SUÁREZ J, NELSON R, LOS S, COOK B, NORTH P 2012 Lidar Remote Sensing for Biomass Assessment. In: Fatoyinbo T (ed) Remote Sensing of Biomass - Principles and Applications. InTech, Rijeka, pp 3-26

39. VASTARANTA $M$, HOLOPAINEN $M, Y U X$, HAAPANEN R, MELKAS T, HYYPPÄ J, HYYPPÄ H 2011 Individual tree detection and area-based approach in retrieval of forest inventory characteristics from low-pulse airborne laser scanning data. Photogrammetric Journal of Finland 22 (2): 1-13 
40. N/ESSET E 1997 Determination of mean tree height of forest stands using airborne laser scanner data. ISPRS J Photogramm 52 (2): 49-56

41. N/ESSET E 1997 Estimating timber volume of forest stands using airborne laser scanner data. Remote Sens Environ 61 (2): 246-253

42. N/ESSET E 2002 Predicting forest stand characteris-tics with airborne scanning laser using a practical two-stage procedure and field data. Remote Sens Environ 80 (1): 88-99

43. LINDBERG E, HOLLAUS M 2012 Comparison of Methods for Estimation of Stem Volume, Stem Number and Basal Area from Airborne Laser Scanning Data in a Hemi-Boreal Forest. Remote Sens 4 (4): 1004-1023

44. COOPS N C, HILKER T, WULDER M, ST-ONGE B, NEWNHAM G, SIGGINS A, TROFYMOW J A 2007 Estimating canopy structure of Douglas-r forest stands from discrete-return LiDAR. Trees-Struct Funct 21 (3): 295-310

45. GONZALEZ-FERREIRO E, DIÉGUEZ-ARANDA U, MIRANDA D 2012 Estimation of stand variables in Pinus radiata $D$. Don plantations using different LiDAR pulse densities. Forestry 85 (2): 281-292

46. JÄRNDSTEDT J, PEKKARINEN A, TUOMINEN $S$, GINZLER C, HOLOPAINEN M, VIITALA R 2012 Forest variable estimation using a high-resolution digital surface model. ISPRS J Photogramm 74 : 78-84

47. ALBERTI G, BOSCUTTI F, PIROTTI F, BERTACCO C, DE SIMON G, SIGURA M, CAZORZI F, BONFANTI P 2013 A LiDAR-based approach for a multi-purpose characterization of Alpine forests: an Italian case study. iForest 6: 156-168

48. SMREČEK R, DANIHELOVÁ Z 2013 Forest stand height determination from low point density airborne laser scanning data in Roznava Forest enterprise zone (Slovakia). iForest 6: 48-54

49. HOLMGREN J, JONSSON T 2004 Large scale airborne laser scanning of forest resources in Sweden. International Archives of Photogrammetry, Remote Sensing and Spatial Information Sciences 36 (8): 157-160

50. CORONA P, FATTORINI L 2008 Area-based LiDARassisted estimation of forest standing volume. Can J Forest Res 38 (11): 2911-2916

51. BARBATI A, CHIRICI G, CORONA P, MONTAGHI A, TRAVAGLINI D 2009 Area-based assessment of forest standing volume by field measurements and airborne laser scanner data. Int J Remote Sens 30 (19): 5177-5194
52. PACKALÉN P, MEHTÄTALO L, MALTAMO M 2011 ALS-based estimation of plot volume and site index in a eucalyptus plantation with a nonlinear mixed-effect model that accounts for the clone effect. Ann For Sci 68 (6): 1085-1092

53. ESTORNELL J, RUIZ L A, VELÁZQUEZ-MARTí B, HERMOSILLA T 2012 Estimation of biomass and volume of shrub vegetation using LiDAR and spectral data in a Mediterranean environment. Biomass Bioenerg $46: 710-721$

54. N/ESSET E 2004 Estimation of above- and belowground biomass in boreal forest ecosystems. International Archives of Photogrammetry, Remote Sensing and Spatial Information Sciences 36 (8): 145-148

55. KANKARE $V$, VASTARANTA $M$, HOLOPAINEN $M$, RÄTY, YU X, HYYPPÄ J, HYYPPÄ H, ALHO P, VIITALA R 2013 Retrieval of Forest Aboveground Biomass and Stem Volume with Airborne Scanning LiDAR. Remote Sens 5 (5): 2257-2274

56. PATENAUDE G, HILL R A, MILNE R, GAVEAU D L A, BRIGGS B B J, DAWSON T P 2004 Quantifying forest above ground carbon content using LiDAR remote sensing. Remote Sens Environ 93 : 368-380

57. STEPHENS P R, KIMBERLEY M O, BEETS P N, PAUL T S H, SEARLES N, BELL A, BRACK C, BROADLEY J 2012 Airborne scanning lidar in a double sampling forest carbon inventory. Remote Sens Environ 117: 348-357

58. RIAÑO D, VALLADARES F, CONDÉS S, CHUVIECO E 2003 Estimation of effective leaf area index, tree height, and covered ground from airborne laser scanner (Lidar) in two contrasting forests. Agr Forest Meteorol 124 (3-4): 269-275

59. MORSDORF F, KÖTZ B, MEIER E, ITTEN KI, ALLGÖWER B 2006 Estimation of LAl and fractional cover from small footprint airborne laser scanning data based on gap fraction. Remote Sens Environ 104 (1): $50-61$

60. RICHARDSON J J, MOSKAL L M, KIM S-H 2009 Modeling approaches to estimate effective leaf area index from aerial discrete-return LIDAR. $\square$ Agr Forest Meteorol 149 (6-7): 1152-1160

61. RIAÑO D, MEIER E, ALLGÖWER B, CHUVIECO E, USTIN S L 2003 Modeling airborne laser scanning data for the spatial generation of critical forest parameters in fire behavior modeling. Remote Sens Environ 86 (2): 177-186

62. RIAÑO D, CHUVIECO E, CONDIS S, GONZALEZMATESANZ J, USTIN S L 2004 Generation of crown bulk density for Pinus sylvestris from LIDAR. Remote Sens Environ 92 (3): 345-352 
63. ANDERSEN H-E, REUTEBUCH S E, MCGAUGHEY R J 2006 A rigorous assessment of tree height measurements obtained using airborne lidar and conventional field methods. Can J Remote Sens 32 (5): 355-366

64. N/ESSET E, ØKLAND T 2002 Estimating tree height and tree crown properties using airborne scanning laser in a boreal nature reserve. Remote Sens Environ 79 (1): 105-115

65. PERSSON Å, HOLMGREN J, SÖDERMAN U 2002 Detecting and measuring individual trees using an airborne laser scanner. Photogramm Eng Rem S 68 (9): 925-932

66. POPESCU S, WYNNE R, NELSON R 2003 Measuring individual tree crown diameter with lidar and assessing its influence on estimating forest volume and biomass. Can J Remote Sens 29 (5): 564-577

67. MALTAMO M, MUSTONEN K, HYYPPÄ J, PITKÄNEN J, YU X 2004 The accuracy of estimating individual tree variables with airborne laser scanning in boreal nature reserve. Can J Forest Res 34 (9): 1791-1801

68. KOCH B, HEYDER U, WEINACKER H 2006 Detection of Individual Tree Crowns in Airborne Lidar Data. Photogramm Eng Remote $S 72$ (4): 357-363

69. SOLBERG S, NAESSET E, BOLLANDSAS O M 2006 Single Tree Segmentation Using Airborne Laser Scanner Data in a Structurally Heterogeneous Spruce Forest. Photogramm Eng Remote S 72 (12): 1369-1378

70. HEURICH M 2008 Automatic recognition and measurement of single trees based on data from airborne laser scanning over the richly structured natural forests of the Bavarian Forest National Park. For Ecol Manag 255 (7): 2416-2433

71. HIRATA Y, FURUYA $N$, SUZUKI M, YAMAMOTO $\mathrm{H}$ 2009 Airborne laser scanning in forest management: individual tree identification and laser pulse penetration in a stand with different levels of thinning. Forest Ecol Manag 258 (5): 752-760

72. LI W, GUO Q, JAKUBOWAKI M K, KELLY M 2012 A New Method for Segmenting Individual Trees from the Lidar Point Cloud. Photogramm Eng Remote $S 78$ (1): 75-84

73. GAVEAU D L A, HILL R A 2003 Quantifying canopy height underestimation by laser pulse penetration in small-footprint airborne laser scanning data. Can J Remote Sens 29 (5): 650-657

74. LECKIE D, GOUGEON F, HILL D, QUINN R, ARMSTRONG L, SHREENAN R 2003 Combined high- density lidar and multispectral imagery for individual tree crown analysis. Can J Remote Sens 29 (5): 633-649

75. YU X, HYYPPÄ J, HYYPPÄ H, MALTAMO M 2004 Effects of flight altitude on tree height estimation using airborne laser scanning. International Archives of Photogrammetry, Remote Sensing and Spatial Information Sciences 36 (8): 96-101

76. MORSDORF F, MEIER E, KOETZ B, ITTEN K I, DOBBERTIN M, ALLGÖWER B 2004 LIDAR-based geometric reconstruction of boreal type forest stands at single tree level for forest and wildland re management. Remote Sens Environ 92 (3): 353-362

77. FALKOWSKI M J, SMITH A M S, HUDAK A T, GESSLER P E, VIERLING L A, CROOKSTON N L 2006 Automated estimation of individual conifer tree height and crown diameter via two-dimensional spatial wavelet analysis of lidar data. Can J Remote Sens 32 (2): 153-161

78. HUNTER M O, KELLER M, VITORIA D, MORTON D C 2012 Tree height and tropical forest biomass estimation. Biogeosciences 10: 10491-10529.

79. NELSON R, SWIFT R, KRABILL W 1988 Using airborne lasers to estimate forest canopy and stand characteristics. J Forest 86 (10): 31-38

80. TAKAHASHI T, YAMAMOTO K, SENDA Y, TSUZUKU M 2005 Estimating individual-tree heights of sugi (Cryptomeria japonica D. Don) plantations in mountainous areas using small-footprint airborne LiDAR. J Forest Res-JPN 10 (4): 135-142

81. HYYPPÄ J, INKINEN M 1999 Detecting and estimating attributes for single trees using laser scanner. Photogrammetric Journal of Finland 16 (2): 27-42

82. HOLLAUS M, WAGNER W, EBERHÖFER C, KAREL W 2006 Accuracy of large-scale canopy heights derived from LiDAR data under operational constraints in a complex alpine environment. ISPRS J Photogramm 60 (5): 323-338

83. VÉGA C, DURRIEU S 2011 Multi-level Itering segmentation to measure individual tree parameters based on Lidar data: Application to a mountainous forest with heterogeneous stands. Int J Appl Earth Obs 13 (4): 646-656

84. VAUHKONEN J 2010 Estimating crown base height for Scots pine by means of the 3D geometry of airborne laser scanning data. Int J Remote Sens 31 (5): $1213-1226$

85. POPESCU S C 2007 Estimating biomass of individual pine trees using airborne lidar. Biomass Bioenerg 31 (9): 646-655 
86. ANJIN C, YONGMIN K, YONGIL K, YANGDAM 2012 Estimation of Individual Tree Biomass from Airborne Lidar Data using Tree Height and Crown Diameter. Disaster Advances 5 (4): 360-365

87. NAKAI Y, HOSOI F, OMASA K 2009 Estimating carbon stock of coniferous woody canopy trees using airborne lidar and passive optical senser. In: Bretar $F$, Pierrot-Deseiligny M, Vosselman $\mathrm{G}$ (eds) Laser scanning 2009. IAPRS, Paris, France. Vol 36, Part 3/W8, pp 289-292. Available at: http://park.itc.u-tokyo.ac.jp/ joho/Omasa/463.pdf (Accessed: 25 May 2013)

88. HATAMI F 2012 Carbon estimation of individual trees using high laser density of airborne lidar (a case study in Bois-Noir, France). Master thesis, Faculty of Geo-Information, Science and Earth Observation, University of Twente, $\mathrm{p} 164$

89. KIM S 2007 Individual tree species identification using LIDAR- derived crown structures and intensity data. Dissertation, University of Washington, Washington, $\mathrm{p} 122$

90. KIM S, MCGAUGHEY R J, ANDERSEN H-E, SCHREUDER G 2009 Tree species differentiation using intensity data derived from leaf-on and leaf-off airborne laser scanner data. Remote Sens Environ 113 (8): 15751586

91. VAUGHN N R, MOSKAL L M, TURNBLOM E C 2012 Tree Species Detection Accuracies Using Discrete Point Lidar and Airborne Waveform Lidar. Remote Sens 4 (2): 377-403

92. WAGNER W, HOLLAUS M, BRIESE C, DUCIC V 2008 $3 \mathrm{D}$ vegetation mapping using small-footprint fullwaveform airborne laser scanners. Int J Remote Sens 29 (5): 1433-1452

93. ØRKA H O, N/ESSET E, BOLLANDSÅS O M 2009 Classifying species of individual trees by intensity and structure features derived from airborne laser scanner data. Remote Sens Environ 113 (6): 1163-1174

94. DONOGHUE D N M, WATT P J, COX N J, WILSON J 2007 Remote sensing of species mixtures in conifer plantations using LiDAR height and intensity data. Remote Sens Environ 110 (4): 509-522

95. PERSSON Å, HOLMGREN J, SÖDERMAN U, OLSSON H 2004 Tree species classification of individual trees in Sweden by combining high resolution laser data with high resolution near infrared digital images. International Archives of Photogrammetry, Remote Sensing and Spatial Information Sciences 36 (8): 204-207

96. DALPONTE M, BRUZZONE L, GIANELLE D 2008 Fusion of hyperspectral and LIDAR remote sensing data for classification of complex forest areas. IEEE T Geosci Remote 46 (5): 1416-1427
97. HOLMGREN J, PERSSON A, SÖDERMAN U 2008 Species identification of individual trees by combining high resolution LIDAR data with multispectral images. Int J Remote Sens 29 (5): 1537-1552

98. VERRELST J, GEERLING $G$ W, SYKORA $K$ V, CLEVERS J G P W 2009 Mapping of aggregated floodplain plant communities using image fusion of CASI and LiDAR data. Int J Appl Earth Obs 11 (1): 83-94

99. DINULS R, ERINS G, LORENCS A, MEDNIEKS I, SINICA-SINAVSKIS J 2012 Tree Species Identification in Mixed Baltic Forest Using LiDAR and Multispectral Data. IEEE J Sel Top Appl 5 (2): 594-603

100. SELETKOVIĆ A, PERNAR R, ANČIĆ M, SUČIĆ JELENA 2011 Assessment of stand structural elements on the basis of spectral reflectance values of an IKONOS satellite image. Croat J For Eng 32 (1): 329-343

101. BALENOVIĆ I, SELETKOVIĆ A, PERNAR R, MARJANOVIĆ H, VULETIĆ D, PALADINIĆ E, KOLIĆ J, BENKO M 2011 Digital Photogrammetry - State of the Art and Potential for Application in Forest Management in Croatia. South-East Eur For 2 (2): 81-93

102. BALENOVIĆ I, SELETKOVIĆ A, PERNAR R, MARJANOVIĆ H, VULETIĆ D, BENKO M 2012: Comparison of Classical Terrestrial and Photogrammetric Method in Creating Management Division. In: Pentek T, Poršinsky T, Šporčić M (eds) Proceedings of 45th International Symposium on Forestry Mechanization: "Forest Engineering - Concern, Knowledge and Accountability in Today's Environment". Forestry Faculty of University Zagreb, Zagreb, pp 1-13

103. BALENOVIĆ I, MARJANOVIĆ H, INDIR K, VULETIĆ D, OSTROGOVIĆ M Z, BENKO M 2013 Estimation of the Stands' Arithmetic Mean Diameter using Manual Method of Digital Photogrammetry. Period Biol 115 (3): $399-407$

104. PACKALÉN P, MALTAMO M 2008 Estimation of species-specific diameter distributions using airborne laser scanning and aerial photographs. Can J Forest Res 38 (7): 1750-1760

105. N/ESSET E, GOBAKKEN T, HOLMGREN J, HYYPPÄ H, HYYPPÄ J, MALTAMO M, NILSSON M, OLSSON H, PERSSON A, SODERMAN U 2004 Laser scanning of forest resources: The Nordic experience. Scand J Forest Res 19 (6): 482-499

106. KAARTINEN $H$, HYYPPÄ J, YU $X$, VASTARANTA $M$, HYYPPÄ H, KUKKO A, HOLOPAINEN M, HEIPKE C, HIRSCHMUGL M, MORSDORF F, N/ESSET E, PITKÄNEN J, POPESCU S, SOLBERG S, WOLF B M, WU J-C 2012 An International Comparison of Individual Tree Detection and Extraction Using Airborne Laser Scanning. Remote Sens 4 (4): 950-974 
107. ČAVLOVIĆ J 2010 The first national forest inventory Republic of Croatian. Ministry of Regional Development, Forestry and Water Management, Zagreb, p 296

108. ŠPANJOL Ž, ROSAVEC R, BARČIĆ D, GALIĆ I 2011 Flammability and Combustibility of Aleppo Pine (Pinus halepensis Mill.) Stands. Croat J For Eng 32 (1): 121-129
109. IPCC 2013 Working Group I Contribution to the IPCC Fifth Assessment Report Climate Change 2013: The Physical Science Basis, Summary for Policymakers. Available at: http://www.climatechange2013.org/images/uploads/WGIAR5 SPM Approved27Sep2013.pdf (Accessed: 1 October 2013) 